\title{
When "Germany" became the new "France"? Royal Dining at the Bavarian Court of Maximilian II and the Political Gastronomy of Johann Rottenhöfer in Transnational European Perspective, 1830-1870
}

DOI 10.1515/irsr-2017-0006

Received: February 1, 2016; Accepted: December 20, 2016

\begin{abstract}
While France defined European hâute cuisine (royal dining for the purpose of expressing rankdistinction) around 1800, by the mid-nineteenth century the French court failed to hold the best chefs of Europe. Other European courts were rising in power and asserting their absolutist ideals in the century of revolution and socio-political change using meals. Within this context, the culinary art of Johann Rottenhöfer in service of Maximilian II of Bavaria synthesized Antonin Carême's hâute cuisine and Jean Anthelme Brillat-Savarin's "political gastronomy" to communicate peace, foster international bonds, and establish equality among sovereigns. The works of Lévi-Strauss and Norbert Elias find resonance in these culinary practices, wherein monarchs were represented at the table in the form of food. Mid-nineteenth century European monarchs not only appreciated the cultural symbolism and the political significance of food, but actively exploited it as a form of communication. I rely on the typologies provided by Ken Albala and Sara Peterson to decode food meanings in the cookbooks written by royals' chefs after retirement.
\end{abstract}

Keywords: Johann Rottenhöfer, Political Gastronomy, Maximilian II, Hâute Cuisine, Antonin Carême, Jean Anthelme Brillat-Savarin

*Corresponding author: Claudia Kreklau, Department of History, Emory University, E-mail: claudia.kreklau@emory.edy

\section{Introduction}

At the time of Louis XIV and in the century that followed, "[m]enus were...written in French, rulers hired French chefs, served dishes devised by the French or made them look like them.” (Albala, 2011: 24) After the French Revolution and Napoleon's demise, however, it seemed that the culinary spirit of the age was beginning to rest elsewhere. France's political history between 1815 and 1914 is well explored, and the instability as the nation went from republic to empire to republic to war was no small disaster, indeed, such a transformation of both French government and society meant that soon, the rulers of the Grande Nation, be they democratically elected or Emperor, could no longer attract the very best cooks to serve their palates. (Lair, 2011:143-170) Instead, the master cooks of their time, Émile Bernard, (Lair, 2011: 156) Urbain Dubois, Jules Gouffé, (Sitwell, 2013) Auguste Escoffier, and Johann Rottenhöfer served either the French bourgeoisie, or else, courts further east.

This article discusses the cuisine of Johann Rottenhöfer, personal chef to King Maximilian II of Bavaria, who, like his celebrated French counterparts, served a German monarch in the mid-nineteenth century. Many authors have noted that "royal taste" in the era after the Sun King conveyed "clear political messages" as sovereigns dined on food "befitting majesty."1 (Albala, 2011: 24) What this article demonstrates is that while rulers such as Napoleon III or Queen Victoria no longer emphasized their majesty through culinary practice, the monarchs of the up-and-coming powers of Europe in Central Europe took their place. While this short

1 Note the recent edited volume on the subject matter, to which this paper is greatly indebted: Vooght, 2013. 
contribution can only examine the political gastronomy of one court in detail, and draw broader transnational connections using limited sources and a valuable secondary literature, it suggests that the self-presentation through food by the King of Prussia, the King of Bavaria, and the Tsar of Russia Nicholas I began to surpass that of the previously unrivalled trend-setter further West. As power-relations shifted in the post-revolutionary period at a European level, culinary practices and the self-presentation through food of German kings reflected said change, and while the Prussian king Wilhelm I employed two French cooks who presented dishes to him representing an autocratic modernity, the Bavarian king's personal chef had other instructions: to cook for peace. Europe's great powers Russia, Britain, Prussia, Austria and France after Napoleon's defeat in 1814 redistributed Europe's land at the Congress of Vienna in 1815. Bavaria, as the largest and most powerful state of the Confederation of the Rhine established by Napoleon in 1806, was caught between Prussia and Austria in their struggle for influence within the successor German Confederation, until Prussia defeated Austria in 1866. Throughout this period, the King of Bavaria had to choose with whom to align: Austria, like Bavaria, was Catholic, yet Prussia was the greater military power, and more likely to unify the German States than Austria. The cooking of Maximilian II's chef Johann Rottenhöfer reflected the king's policy: both communicated peace. Chef Rottenhöfer's political gastronomy aimed to lay the groundwork for equality among sovereigns, and encourage acceptance of current borders. Maximilian II's political policies could be read from his dining.

After Claude Lévi-Strauss, Mary Douglas, and Norbert Elias set the agenda for exploring food-choices determined by cultural meaning rather than physiological preference-an idea Sarah Peterson has recently brought to completion-studies of food and foodways in the past fifty years have confirmed over and again that "food is culture.” (Scholliers, 2012: 60; Lévi-Strauss, 1963, 1973, 1983; Peterson, 1994; Montanari, 2006) Like a language, food functions as a system of signifiers for political conditions and the social organization of a community, its ingredients, cooking methods, and forms of presentation expressing "the very core (or structure) of a society." (Vooght and Scholliers, 2011: 4-5)

This article reads food as a language, wherein subjective cultural associations function as the signifiers of a culinary system of ingredients, cooking methods, and presentation styles that aim to construct a symbolic image of the monarch, their power, and the influence of their court at the international sphere. Irrespective of the objective realities of their aims, this article points out how throughout this era of social change and reallocation of power within Europe, self-image and self-presentation in dining practices communicated domestic and international policy.

The culinary practices at the Bavarian court between 1848 and 1864 reflect the monarch's assertion of his divine right in his choice to dine majestically in order to reflect his aspirational and then quite realistic grasp for influence in the era of France's instability. The relative typology at the basis of this culinary code we draw from Ken Albala and Sarah Peterson, whose bold work on culinary imagery and its political symbolism provide historians with a key to deciphering that rich tongue. (Peterson, 1994) Albala notes that each typologized era of the European past found its way into nineteenth-century dining presentation for its symbolic value: Greek imagery stood for asceticism and democracy; Rome, for empire and splendor; the Medieval period for nationalism; colonial imagery for Orientalism, etc. (Albala, 2011: 13-30) Here, we must note that German Orientalism differed from its French and British counterparts, as Said once noted, and Marchand emphasized more recently. (Said, 1979:1, Marchand, 2009) Peterson meanwhile notes that it was these meanings as contemporaries associated them with political and philosophic ideas that determined their choice of ingredients in the modern era, bringing about our "modern" cooking from France. (Peterson, 1994)

The following narrative begins in France, the former realm of the Sun King, and moves to Russia, whose servicestyle-what we know today as a fixed menu-triumphed in the nineteenth century. We briefly cover Queen Victoria's often unsplendid dining, and note that Prussia's two famous cooks, successfully drawn to Berlin after Parisian unrest in 1830 and 1848, imported some strikingly inclusive modernity to King Wilhelm I's dining table. Finally, we analyze the cooking of Johann Rottenhöfer in this European culinary and political context, and argue that his effort to make peace and establish the groundwork for successful diplomacy in a century of revolution and threatening war show us not only that Maximilian held on to his right to rule, but that his dinners were constructed to make friends in Europe, rather than enemies. We finish with a note on the "Dinner of the Three Emperor's," recently analyzed by Anne Lair, as it synthesizes some of the major trends of hâte cuisine in the period between roughly 1830 and 1870. We acknowledge Sarah Peterson's contribution to culinary history that places the ideal and the political symbolism of food above taste or practicality in the formation of modern dining, and, in the case of this discussion, political dining too. With this short piece, we 
aim to place Johann Rottenhöfer on the map of great cooks of the nineteenth century, and show that an exploration of royal dining at Maximilian II's court and that of some of his peers not only confirms Sidney Mintz's connection between food and power, but indicates that food communicated political aims in mid-century. Classical dining in the style produced by Rottenhöfer and his peers in Prussia and Russia represented these rising imperial powers' last grasp at political absolutism as they not only appreciated the cultural symbolism and the political significance of food, but actively exploited it as a form of communication for political and diplomatic discourse. ${ }^{2}$

\section{The Demise of French Hâute Cuisine at the Court of Napoleon III}

At the turn of the eighteenth to the nineteenth century, unrivalled chef Antonin Carême served Prince Talleyrand, and Napoleon I for his wedding. (Kelly, 2009) Carême, King of Cooks and Cook of Kings here coined the concept of "Hâute Cuisine"-cooking techniques and forms of presentation using choice ingredients to communicate the distinction of the crème de la crème of European society. (Trubek, 2000) At this time Carême noted that outside of France, there was little sense in going to work at a royal court. The budgets were too small, the appreciation of true culinary art too little: only within France, where the means at the disposal of the Head Chef were the highest in all of Europe, could a culinary artist test the limits of his work. (ZDF, 27:15) This changed drastically after 1815, and after serving the Prince of Wales, and cooking for the Grand Duke of Russia, in the spring of 1819, Carême accepted an appointment as Head Chef at the Winter Palace of the Russian Imperial court. The culinary spirit of the age was moving East-ward.

At the court of Napoleon III, meanwhile, argues Anne Lair, the absolutism and majesty of his predecessor ceded to an eclectic and bourgeois, partly modern, and partly extravagant style of dining that attempted to impress with quantity rather than quality. Napoleon III and his wife Eugenie appreciated the need to continue with aspects of

2 Throughout this article we are basing ourselves on the assumption that the books that royal cooks wrote after serving at a royal court for several years are an indicator of how they cooked for monarchs during their employment. This exploration does not cover the development of the Viennese Café, or the French restaurant, a story told elsewhere, nor that of the dining habits of Franz-Joseph I and his empress Elizabeth, whose biographies cover her "modern" anorexia (Ashby, Gronberg and Shaw-Miller, 2013) See: http://menus.free.fr/ index_fichiers/Page3632.htm. royal protocol, but were also very conscious of their need of approval from the larger population. Patchworking dates in remembrance of Napoleon I with nationalistic heroic imagery that appealed to the masses, and inspiration from France's royals' history, Napoleon III produced an eclectic monarchical identity reflected directly in his dining. (Lair, 2011:148) Thus, the "potage à la bourgeoise" was soon followed by "Côtelettes de gibier à la Richelieu" and "Salade de homard à la Russe" on Saturday, the $12^{\text {th }}$ of August 1855, and the "Potages à la bourgeoise", on Friday, $18^{\text {th }}$ of June 1858 , by "Saumon à l'écossaise," "Casserole de riz à la financière," and "Haricots flageolets à la maître d'hotel." [sic] Another menu in 1860 included "Puré à la Reine." (Ibid, 159) The Emperor's meals included cosmopolitan meals, so characteristic of royal dining, some named after distinguished individuals-such as Richelieu-alongside stews in the style of the bourgeoisie.

While the last French Emperor's dining continued to be lavish and sumptuous, always including 14 dishes, the most esteemed chefs of the time did not serve Napoleon, but travelled instead to foreign courts. (Ibid, 158, 160) Émile Bernard very briefly served Napoleon III, but then went on to serve at the Prussian Court of the Hohenzollern family. (Ibid, 156) The same went for Urbain Dubois, with whom Bernard authored the Cuisine Classique. (1882) Urbain, student of Carême's cuisine, worked under Adolphe Dugléré (also a student of Carême) at the Café Anglais to later teach Auguste Escoffier, chef of the Savoy in London. (Neirinck and Poulain, 1988: 70) Anne Lair notes that both Dubois and Barnard chose to "got to a foreign court" to serve William I of Prussia, rather than stay in Paris. (Lair, 2011: 156) That the public bourgeois kitchens of the up and coming hotels and restaurants superseded the French court in culinary splendor is now a well-known story. (Trubek, 2000; Spang, 2001; Ferguson, 2004) Yet, at the same time, we are missing a piece of this tale if we ignore that non-French courts attracted the best chefs of the mid-nineteenth century-from Carême at St Petersburg, to Dubois and Bernard in Prussia.

\section{The Rise of Russian Style Service: Nicholas l's Reassertion of Distinction, 1825-1855}

In this century of revolutions and uncertainty, the origin of monarchical re-assertion of absolute power and distinction came from Russia. While the French style "open table," where all guests served themselves from the dish closest to them, became popular during Peter the Great's reign, 
and persisted throughout Catherine the Great's, David I. Burrow argues that it was Nicholas I, during his era from 1825 to 1855, who "asserted his vision of his own power and authority through dining and sociable practices" who invented the fixed serving order Service à la Russe "subsequently exported to Western Europe." (Burrow: 2011: 102, 106, 109) While the exact chronology of the exportation of Russian Style predetermined menus differs depending on whom one consults, historians do agree that Russian Style Service popularizing from 1809 to midcentury, has much to do with royal assertions of power and absolutism in a time of change and social upheaval. The Russian aristocracy in St Petersburg and Pushkin thereon, Burrow notes, no longer dined with their Tsar, but watched his dining instead, as the western nobility had done during Middle Ages. Nicholas' dining was thus a spectacle for the aristocracy and nobility to the alienating effect of the Tsar's social proximates.

Some would argue that Service à la Française was more "ostentatious," (Crofton, 2014) or note that the Service à la Russe was more practical, demonstrating some move towards practicality among a monarchy adapting to the time. However, the ingredients of the menus, and the function of dining practices in mid-century do not support these interpretations. In effect, the reduction of choice, and the elimination of the on the one hand egalitarian nature of choosing from various dishes at the same time, as well as the anarchical implication of the former style wherein dishes were not passed around the table, letting consumers only eat the dishes closest to them, should instead be interpreted as a reification of distinction. In the case of Nicholas I's court, this certainly was the case, and it may well have been part of the ordering of dining on a European level more largely, as part of a stricter imposition of hierarchy in nineteenth-century commensality. ${ }^{3}$ (Chevalier and Walter, 2008: 67)

\section{Victoria and Albert: British Constitutional Dining, 1837-1861}

Was this exercise of distinction key in the dining habits of the Queen of England? Surely, the greatest Empire in the world would take care to rival the greats in their dining in mid-century. They did not: at Windsor, Charles Ludington notes, "[t]he royal family became more 'middle class' in its tastes," (Vooght and Scholliers, 2011: 10) and lost any previous splendor after the death of Albert in 1861.

3 The style became popular, argue Adamson and Segar, among the bourgeoisie in the 1880s. (Adamson and Segan, 2008: 226).
(Ludington, 2011:64) The British imperial couple's taste was far from typically "royal." Victoria feared extra weight due to her small frame, and Albert, due to his sensitive constitution and delicate bowels, could not stomach heavy foods. Therefore, their own meals consisted of boiled chicken, roast beef, and soup; the occasional richer foods on Victoria's table included her favorite dish of Indian curry. (Brown, 175-6) Michèle Brown notes that Victoria's first chef Francatelli soon "grew bored" cooking for the Queen, and left. (Ibid, 178) In daily life, the only contradiction to Victoria and Albert's ascetic eating ethos seems to have been that their pastry-chefs were among the best in Europe, including Soyer, Ranieri, Francatelli, and Menager, as well as Jules Gouffeé. (Ibid, 176; Sitwell, 2013) In this sense, Victoria's dining seems to have been "modern" in the sense of combining an effort to make daily eating habits less than grand, with sugar being the great temptation that compensated it.

As Danielle de Vooght and Peter Schollier note, with regard to the constitutional nature of many European monarchs, including Queen Victoria, and despite the particular personal circumstances of her reign, these dining habits may just as well also reflect that Britain's monarchy was not what Henry VIII's had been: while sovereign, they had little "real" power, and culinary practices reflected this, but for the few occasions where appearances and occasions with honored guests demanded greater protocol as part of state-representation. (Vooght and Scholliers, 2011: 8) At Christmas or official feasts, and when hosting their own guard or the Russian imperial family, menus reflected their appreciation of their guests, and asserted the family connection in the latter case. (Albala, 2011: 26) When hosting the Belgian King, on June $30^{\text {th }}$ of 1841 , still during Albert's life-time, for example, the royal dinner included "Royal Sole," "Truffled Spring Chicken", and "Turtle flippers in Madeira wine” as part of a 48-dish prémier service, and 36 dishes as part of the deuxième service to the 40 aristocratic guests. (Clarkson, 2009: 414-5)

\section{Prussian Royal Dining, German Orientalism, and Modern Culinary Spectacle}

If not in France, or Britain, where then did the culinary spirit of the age come to rest to prepare its hâte cuisine? The perhaps surprising answer, given Germany's reputation-or lack of reputation-for fine food, is: in Berlin. Urbain Dubois, after his stay at the Café Anglais in 
Paris, and a while in Russia, settled in Berlin alongside his colleague Émile Bernard, serving Wilhelm I of Prussia, to be the first Emperor of the Germans in 1871. Three salient features of the creations of Dubois and Bernard distinguish their cuisine's style of presentation: fantasy. Dubois and Bernard enjoyed an artistic challenge, noting that at times ornamental pieces unfortunately had to be "sacrificed for lack of time." (Bernard, 1882:2) Their primary aim in cooking was to construct an image of "comfort, luxury, and elegance," and the purpose of food statues to be spectacle: "entertainment." (Bernard, 1882:1) For this, the chefs took a very flexible attitude towards architectural typologies: their work included "classical orders" such as "Moor, Greek, and Gothic," but also "orders of fantasy," visually appealing impressing with complexity and detail loosely based on architectural precedent. (Bernard, 1882: 338) Statues include spires that remind of Saint Basil's Cathedral, Renaissance cornucopias, spires that fuse Moor and East Asian elements, and even a representation of a famous contemporary attraction: a hot air balloon. (Bernard, 1882: 382)

One might expect Oriental decorations (e.g. the 'mauresque' style) to be well-represented among the monarch's meals all over Europe in the time of Empire; yet a comparison of Jules Gouffé's work Le Livre de Cuisine, or Royal Cookery book, written after serving Queen Victoria, and even Antonin Carême's own work Le Pâttisier Royal Parisien, reveals the opposite: the imagery Carême

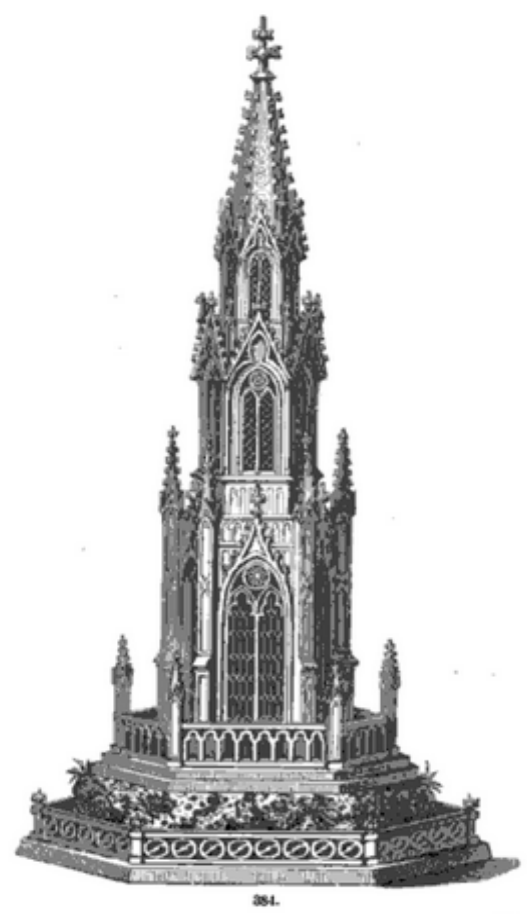

Figure 1: A gothic spire (Bernard, 1882: 353) draws on is overwhelmingly "European", encompassing Greek, Roman, and Medieval romantic imagery for the construction of his architectural achievements in sugar and jelly. (Carême, 1815: 152) Gouffé's work, in turn, contains no complicated forms of representation at all (Figure 4); here, Gouffé diverges greatly from Carême. While Victoria enjoyed her Indian curries, and aristocratic dining certainly included ingredients from the empire, their imagery did not drive this point home. A

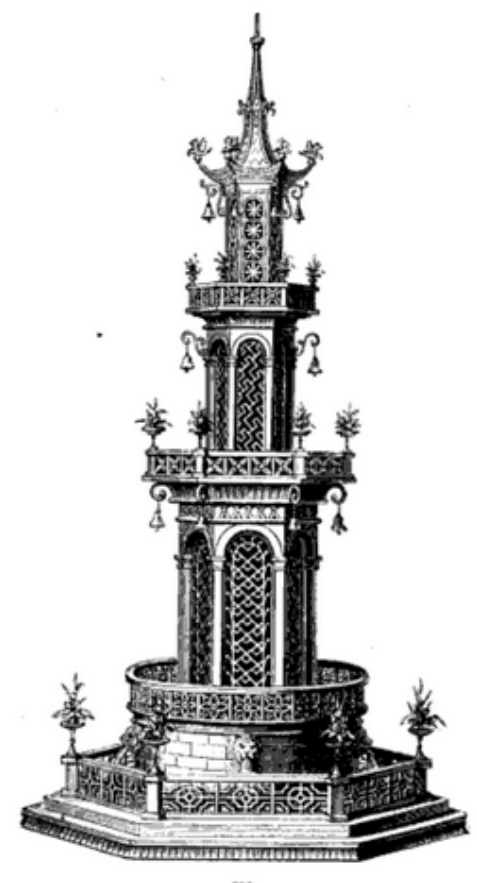

Figure 2: Oriental Spire fusing East Asian Influence with Moorish elements. (Dubois and Bernard, 1882: 363)

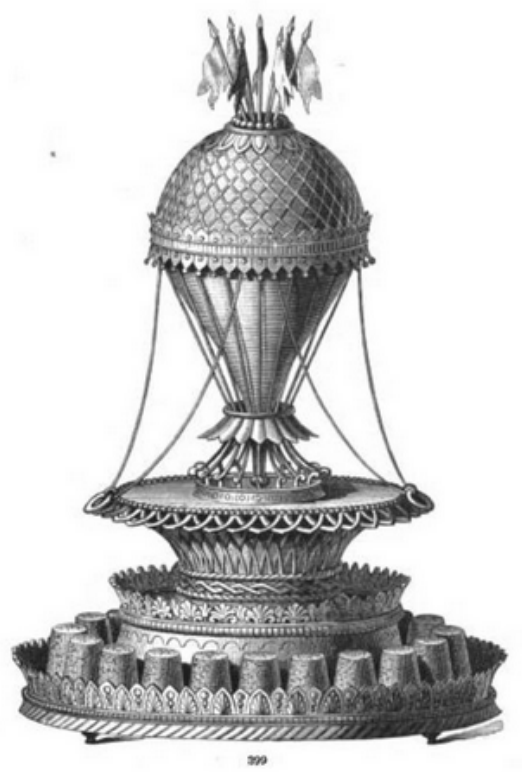

Figure 3: A hot air balloon. (Dubois, 1882: 382) 


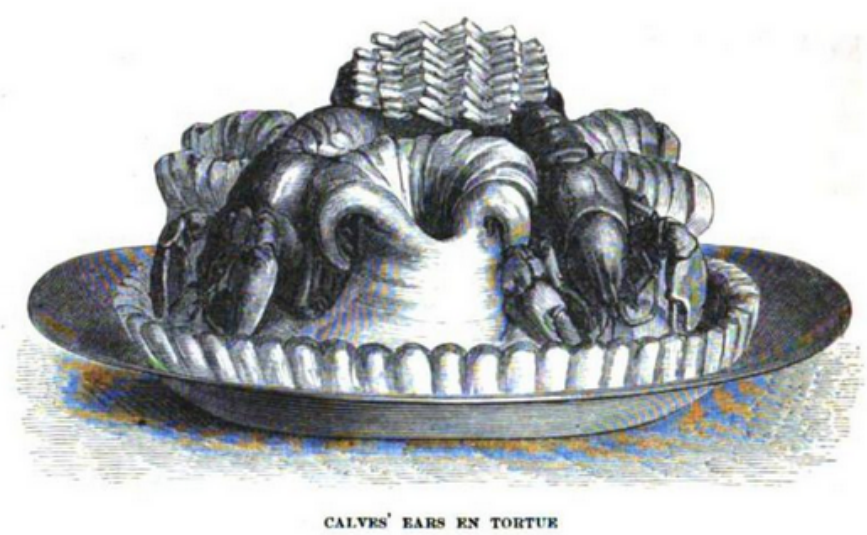

Figure 4: A typical presentation dish by Gouffé: Calves ears “en tortue." (Gouffé, 1869:340)

typical dish in Victoria's household may look as Figure 4 demonstrates, and portray its ingredients quite naturally in a composition that does not attempt to turn food into a primarily aesthetic experience.

Not so at the Prussian court: celebrating status through exuberance beyond what occurred in the kitchens at Windsor and the Tuileries Palace, Prussia's dining table indicated a rather "modern" celebration of the visual, predating the culture of spectacle in fin-de-siècle Paris, and a striking experimental inclusiveness and respect for architectural quality and cultural achievement as perceived by contemporaries. (Schwartz, 1998) Note the mudejar arches, reminiscent of the Muslim rule in Spain, as in Figure 5 on the right hand side in Dubois and Bernard's work. The Corinthian columns in the center, and the hybrid on the right hand side, combining the gothic with some middle eastern influence stand for the more common Roman and Romantic influences in nineteenth-century cooking that Ken Albala notes in his work on architectural typologies in the era after Carême. The left arch, however, was less than common in Central European or Classical dining.

Even less common, was the use of Oriental spires (Figure 2) and the combination of far-eastern roofs with intricate near eastern carvings speak for the nineteenthcentury European imagination of the East. At a time when German-speaking scholars were leaders in archaeological research in the Holy Lands and travel eastward, Prussia's chefs integrated all elements of Orient, Occident, past and present into their art, treating them thus as equals. (Marchand, 2009) Perhaps such a representation was possible precisely because Prussia had no empire nor supported expansion under Wilhelm I and Otto von Bismarck. Dubois and Bernard's cooking, though primarily aesthetic and spectacular, kept "tradition"
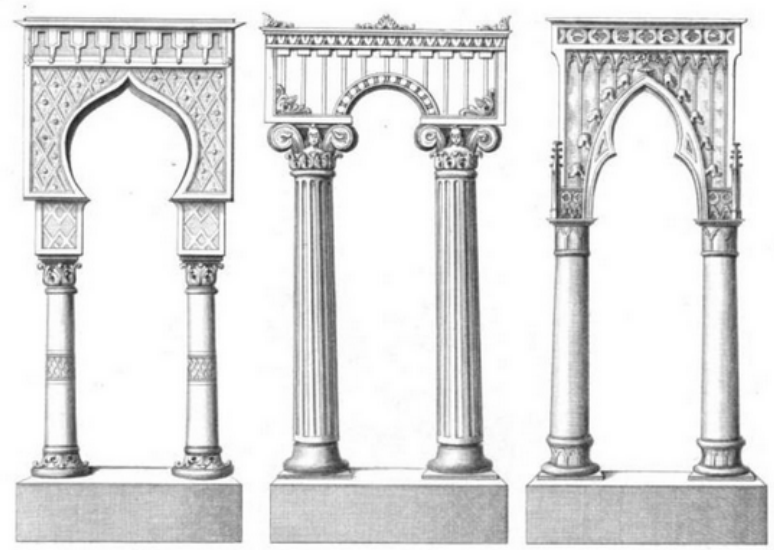

Figure 5: Hardened animal fat carved into decorative columns for presenting cold meat cuts. (Dubois and Bernard, 1882: 72)

(Bernard, 1882: 1) and reinforced royal status above and beyond what Victoria's and Napoleon III's chefs did, but in doing so merely placed Prussia's absolutists in an increasingly "modern" imperial world.

\section{"Political Gastronomy" at the Court of Maximilian II of Bavaria: the work of Chef Johann Rottenhöfer, 1848-1864}

If we consider Carême as the royal cook par excellence, and his influence as an indicator of truly royal dining, then Prussia's consumption is the heir to that tradition in midcentury, rather than either Britain or France. Alongside Prussia in the continuation of Carême's classical cuisine stands Bavaria, whose cuisine and presentation not only adopted Carême's achievements, but developed them. In terms of cuisine, Rottenhöfer succeeded in bringing Carême's artistic presentations to a new level: the primary goal of Johann Rottenhöfer's cooking was peacekeeping.

Johann Rottenhöfer (1806-1872) served Maximilian II of Bavaria as personal chef (Mundkoch) between 1848 and 1864, and later as his majordomo (Haushofmeister).(Project Gutenberg: 2014; Reiser, 2000: 25 and 33) He published his magnum opus, the New complete theoretical and practical instruction in the finer art of cooking (Neue vollständige theoretisch-praktische Anweisung in der feinern Kochkunst) in $1858 .{ }^{4}$ Years after the end of his service as cook, in the second edition of 1867 , he added a few last recipes to his initial collection and added a prologue which summarized

4 All translations my own. 
his views on the key importance of gastronomy to politics. ${ }^{5}$ (Rottenhöfer, 1867: 1024)

Some would note that Rottenhöfer was "one of the leading cooks of the nineteenth century," at least in Central Europe, and his cookbook has been called "the best cookbook of its time.” (Project Gutenberg, 2014) While it is difficult to put labels on or impose comparative hierarchies among both cooks (whose food we have not tasted) or their works, we observe that the degree of careful political calculation in the expository tone, the choice of ingredients, the composition of menus, and the imagery of presentation in Rottenhöfer's work speaks for a now underestimated and undeservedly forgotten genius in nineteenth-century cooking.

Rottenhöfer, while learning from Carême, was also a student of Jean Anthelme Brillat-Savarin and his "political gastronomy." As outlined in Brillat-Savarin's Physiology of Taste (Physiologie du Gout, 1825, translated as Physiologie des Geschmacks, 1865, by Carl Vogt), Rottenhöfer insisted that "the hungry man is not the same as the full", and that "[m]eals have become a means of government" (Regierungsmittel). ${ }^{6}$ (Rottenhöfer, 1867: 8) He noted that "food makes the guests more open and receptive to certain influences" (Ibid) and wrote, like Brillat-Savarin, that the "fate of nations rises and falls with their dining." (BrillatSavarin, 1826: xiii)

Rottenhöfer understood his craft as providing the diplomatic basis-neutral, egalitarian (among monarchs), and respectful-for political negotiations and alliances. To him, dining was an integral part of high politics. The act of sharing a meal forged alliances, "weav[ing] a bond between host and hosted.” (Rottenhöfer, 1867: 8) This idea was fairly well-known among the educated of Central Europe. Hermann Lessing, for example, describes "political gastronomy" as "a science of the peace of nations" (Völkerfriedens) in his Parisian Rambles of 1854. (Lessing, 1854: 77) Within Rottenhöfer's sober, coherent, and clever text aimed at educating the young cuisiniers of Central Europe, the king's personal chef held these ideas in a context of duty: he insisted that "Gastronomy considers humans and things in order to bring all that which is worth knowing (alles Kennenswerthe) from one country to another, so that an artfully ordered meal is at the same time an epitome of the whole world, wherein each country is represented in the most advantageous

5 The 1867 edition of Rottenhöfer's work was to be the definitive version and suffered no further major modifications until 1904, when the work was first bound in single monographic format.

6 See also Minna von Strantz. Unsere Gemüse: mit Anchluss der Kastanie, Olive, Kaper, der Wein- und Hopfenrebe. Berlin: Enslin, 1877, xi. manner.” (Rottenhöfer, 1867: 7) Gastronomy was, in fact, high politics.

Rottenhöfer drew the style of presenting-dishes from Carême's cuisine with, for example, ice and jelly statues Carême was famed for (Figure 6), and the Romanstyle architectural lines guiding the creation of heavily embellished stands of animal fat carved into shape and decorated for the presentation of cold cuts and entrées at balls and diners (Figure 7). (Rottenhöfer, 1867: 648, 972-5)

Johann Rottenhöfer's depiction of Roman-style columns had the purpose of drawing an aesthetic and imagined connection between the splendor of Ancient Rome with that of his monarch, as accessed through Carême's cuisine. This neo-classicism, as Ken Albala points out, does not necessarily reflect an accurate depiction of Roman politics or history, but instead served

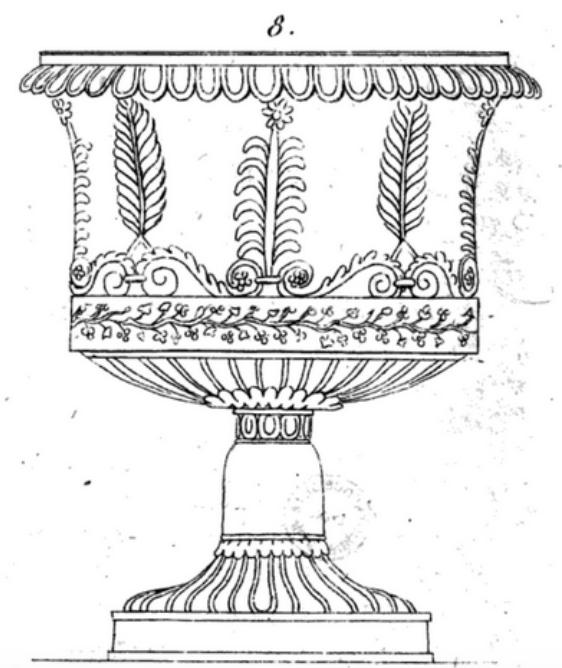

Figure 6: Roman style presentation cup for desserts and sweet dishes made in sugar or jelly. (Carême, 1815:214)

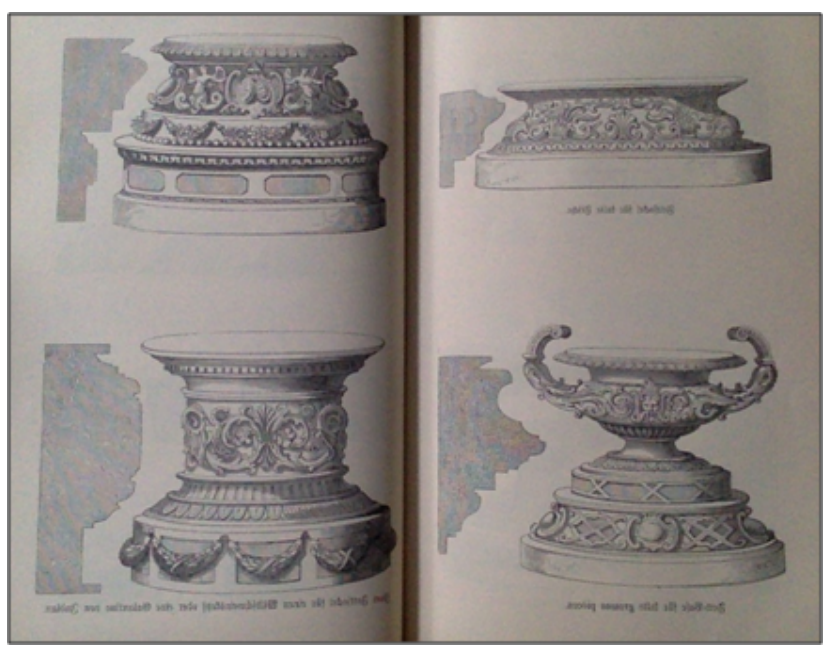

Figure 7: "Fettsockel": bases or stands carved out of blocks of hard pork and mutton fat. (Rottenhöfer, 1867: 972-975) 
the purpose of conjuring up the image of empire, allowing contemporaries to read similarities between contemporary monarchs and past decadence and power. (Albala, 2011) It is this imagery that Rottenhöfer exploits in his creation of royal meals.

French fashion reminiscent of the Sun King's Baroque style, of course, formed part of Rottenhöfer's dining design as well. For example, in the presentation of cold soups, the Bavarian court, like other courts such as Spain's, made sure to use the silverware and crockery that Louis XIV had made fashionable. (Figure 8; Palmer, 1997:133) $\mathrm{He}$, as well as his peers all over Europe, also adopted the Service à la Russe established by Nicholas I in this time. Rottenhöfer's explanation of the change in service was as diplomatic as the rest of his cooking: French style service "causes most foods to become cold, and, due to the practice of keeping it warm, brings about the so-called re-heated taste." (Rottenhöfer, 1867: 960) This almost scientific-sounding explanation illustrates the political correctness and caution dictating the culinary choices at the Bavarian royal palace, and is a good sample of the tone of Rottenhöfer's cookbook wherein he consistently states his absolute political neutrality.

Rottenhöfer's insistence that "Gastronomy considers humans and things in order to bring all that which is worth knowing" together in "an artfully ordered meal" established that the meal was "an epitome of the whole world, wherein each country is represented in the most advantageous manner.” (Rottenhöfer, 1867: 7) Here, Rottenhöfer rings so much of Lévi-Strauss and Elias, that to suppose Bavaria's chef sought to construct a parallel between cosmos and food is not a stretch. Highly orchestrated and more than carefully planned out, to

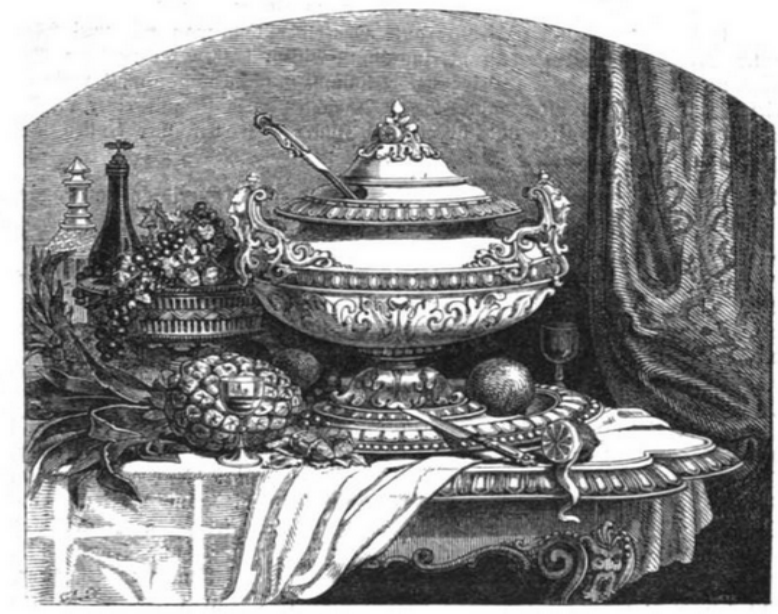

1. A6[dfnitt. 4. A6tgeitung.

Kon ben talteu Suppeu, Raltílalen. Des Soupes froides.

Figure 8: Presenting bowl for cold soups. (Rottenhöfer, 1859: 70) consume the food of another territory, in the presence of its ruler, was a sign of honor from the host, and a tacit expression of recognition of their representation of their lands made by the host as well as the other guests. Dining was politics. In great part, gastronomy was politics to Rottenhöfer given that when a monarch was present as a guest at the Bavarian court, they were not only represented in the flesh, but, also in the form of food. To Rottenhöfer, monarchs embodied and represented their states. While Rottenhöfer does at one point provide a recipe of the "National Soup of the French", within his culinary art, monarchs represented their lands according to the logic of divine right and Jacques Bossuet, the consumption of foods associated with the territory of another monarch at a festive banquet stood for a sign of mutual appreciation and respect, as well as an acknowledgment of their claims to said lands. (Rottenhöfer, 1867:39) Dynastic claims and their recognition thus formed the basis of their culinary political negotiation. Given that most dishes either carried the name of a country ("French", "Russian”, or "English"), a famous leaders (Richelieu, Mazarin), noble house (Beauharnais) or else royal titles of former patrons (à la Reine), Rottenhöfer and King Maximilian II had a vast political culinary vocabulary at their disposal with which to communicate the desired political messages.

His guests could no doubt respond in kind, and knew not only how to decode culinary messages, but how to interact with them as well. Rottenhöfer certainly did his best to minimize accidental or even intentional affront. In the presentation style of foods, Rottenhöfer took the salient feature of Carême's circle-the perfect form-and applied it across all his designs, except for the few times when he produced sculptures. Dishes at the Bavarian court were overwhelmingly arranged in circles and mounds, with some references to round "pyramidal" shapes. (e.g. Figure 9. Also Rottenhöfer, 1867: 658-9, 865) The egalitarian, Arthurian form, of course, provided the basis for negotiation among equals. If power politics were determined and exercised while dining, this choice was made by the heads of state themselves, and not by those participating in the gastronomic process. (Montanari, 2006: viii) Similarly, when serving oneself from a cold buffet, the choice among identical portions prevented the possibility of taking a share best left to someone else. Both servants and guests could thus tread quite safely. ${ }^{7}$

7 For a discussion on rank-distinction through portion-sizes from the Merovingians through the early modern age see Montanari, 2006:118 and "Tell Me How Much You Eat and I'll Tell You Who You Are”, in Ibid, 115-122. 


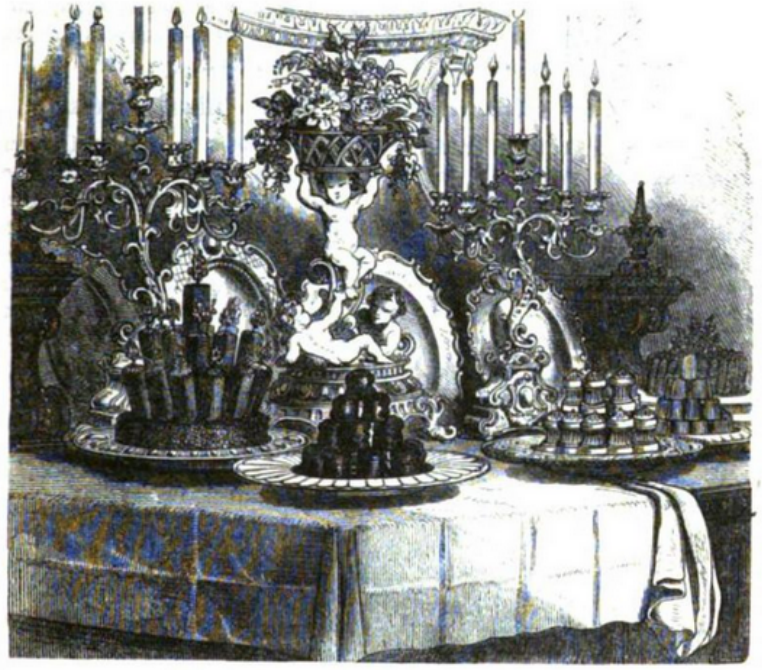

Figure 9: Pyramidal and circular mounds presenting hors-d'oeuvres. (Rottenhöfer, 1859:141)

That Maximilian's peaceful political policies should be reflected in his hosting should probably not surprise us. After studying history, politics, and law at the University of Göttingen, and working with some of the more progressive minds of the century, including the historian Friedrich von Raumer, at this time Frankfurt Parliamentarian, Maximilian counted among the more Idealist of European monarchs. (Deutsche Bibliographie, 2016) Combining an insistence on his absolutism with very hesitant adoption of reforms in mid-century, King Max's dining strove for international peace, even as the extravagant styles of presentation cuisine reasserted his absolutism.

\section{Conclusion}

Before the League of the Three Emperors in 1873, came the "Dinner of the Three Emperors" in 1867. (Lair, 2011) In the early summer of that year, Tsar Alexander II, future Tsar Alexander III, and Wilhelm I of Prussia, soon to be Emperor of Germany, met in Paris at the Café Anglais, and were served by Antonin Carême's student Adolphe Dugléré. They amongst others consumed "Empress Soup," "Queen-style Soufflé," and a "Pan-sear of the Princess." (Clarkson, 365-6) While we may find it particularly curious that the gentlemen dining consumed food in the style of titled dames, absent at that meal, the dinner also included French-style (Breton, Parisienne...), Spanish, and Portuguese dishes. (Ibid, 365) This instance of Frenchdining, emperors of developing power, female absence but in the form of food, at the public restaurant Café Anglais in Paris in the context of its Universal Exposition, synthesizes some of the main cultural trends of this time. The French imperial household under Napoleon III was not what it had been under Napoleon I, nor Louis XVI, nor Louis XIV. The upcoming restaurant, expanding in Paris throughout the nineteenth century, rivaled the former monopoly of splendor of the French crown, and now employed the best chefs of France within Paris. (Spang, 2001; Ferguson, 2004) Central Europe grasped for new power as France, though an imperial power surpassed only by Britain, grew in strength and influence with its post-1850 industrial boom and military developments. Prussia employed the best cooks of its time, and Johann Rottenhöfer synthesized French culinary practices in Bavaria to reflect his sovereign's status and peaceful policies. The dinner of the Three Emperors remains the "most expensive meal in history" and it is key to note who was present, and who was absent. (Lair, 2001: 164) Present were Alexander II and Alexander III, and Wilhelm I. Absent were the local Emperor Napoleon III, and the mourning widow Queen Victoria. The rulers of Europe not only appreciated the cultural symbolism and the political significance of food, but actively exploited it as a form of communication. Their public dining in 1867 was a clear message of their political status, and a reassertion of their absolutist power. The culinary spirit of Europe, it seemed, was moving further East.

Cooking is an art form, and its artists, like others, need stability, resources, and some cultured appreciation of their work. In these regards, the stars of Central Europe in particular were rising. The French cooks of the time sought employment away from the French Imperial court: when we examine the foods of the table of Maximilian II, and note the practices at the Russian and Prussian courts, we reinforce the indubitable connection between food and political power. (Mintz, 1985) If publishing a major work on cookery in imitation of Antonin Carême is some indication of life-time success and later influence, then Johann Rottenhöfer deserves a spot on the Frenchdominated map of nineteenth-century European cooking, a map covering a political landscape that in his time was changing. When Sarah Peterson noted that French cooking synthesized the thought, philosophy, and reality constructions of the ancient world and Italian Renaissance cuisine, she argued that the meaning of food predetermined ingredients' successes due to its political symbolism. While we would most naturally assume that consumers prefer foods that they are either accustomed to, or else, those we tend towards for survival, Peterson argues that all tastes-culturally speaking-are acquired, and that they were selected because, to quote LeviStrauss, they were "good to think." Their choice reflected 
an expression of philosophical preference, and changes in ideas. First came the thought, then, the ingredients with which to express it. In this manner, Peterson provides us with a two-thousand year history of philosophy, religion, alchemy, and science, wherein food became the social and cultural expression of the nature of reality predominant at the time. Peterson has placed causation and effect on its head: contemporary modern food, she argues, drew on baroque and classical France, who drew on Renaissance Italy, who drew on Rome, who drew on their Empire and the Ancient world more largely. (Peterson, 1994:xiii-xiv) To develop this thought even further, the spirit of the age of her analysis came to rest of the French Restaurant, and its foreign exportations-as many authors, including Rebecca Spang, have noted. (Also: Burnett, 2004) I suggest further that it may also have come to rest, if for a short while, among the aspiring monarchies of Central Europe who sought to combine Roman splendor, French Absolutism, some "modernity" and some patriotism in their rules at the time that monarchy as a form of government saw the beginning of its end. As visible from the culinary style of King Max, and the forms of presentation at the court of Wilhelm I, Central European monarchs used food to express their politics and status. Within this, Maximilian II's pacifism and aim at establishing stability, thanks to Rottenhöfer's intelligent care may have been among the most highly symbolic in his time, even when compared with his contemporary's most sophisticated haute cuisine.

\section{References}

\section{Primary Sources}

Brillat-Savarin, J. A. (1826) Physiologie du goût, ou, Méditations de gastronomie transcendante: ouvrage théorique, historique et à l'ordre du jour. A. Sautelet et Cie libraires.

Brillat-Savarin, J. A. (1865) Physiologie des Geschmacks oder physiologische Anleitung zum Studium der Tafelgenüsse: Den Pariser Gastronomen gewidmet von einem Professor. Übersetzt und mit Anmerkungen versehen von Carl Vogt. Fr. Vieweg $u$. Sohn.

Brown, M. (2006) Eating like a King : A History of Royal Recipes. Stroud: Tempus.

Carême, M. A. (1815) Le Pâtissier Royal Parisien, Ou Traité Élémentaire Et Pratique de La Pâtisserie Ancienne Et Moderne, Suivi D'observations Utiles Au Progrès de Cet Art, Et D'une Revue Critique Des Grands Bals de 1810 Et 1811, Etc.

Clarkson, J. (2009) Menus from History: Historic Meals and Recipes for Every Day of the Year. 2 Vols. Santa Barbara, Calif: Greenwood Press.

Dubois, U. and Émile B. (1882) La cuisine classique: études pratiques, raisonnèes et dèmonstratives de l'école francaise. E. Dentu.
Gouffé, Jules (1869) The Royal Cookery Book: (le Livre de Cuisine). S. Low, son, and Marston.

Lessing, Hermann (1854) Pariser Spaziergänge. Berlin: Allgemeine Deutsche Verlags-Anstalt.

Rottenhöfer, J. (1859) Neue vollständige theoretisch-praktische Anweisung in der feinern Kochkunst mit besonderer Berücksichtigung der herrschaftlichen u. bürgerlichen Küche: Illustrirt v. Em. Drexler, vol.4. München: Braun \& Schneider.

Rottenhöfer, J. (1867) Neue vollständige theoretisch-praktische Anweisung in der feinern Kochkunst mit besonderer Berücksichtigung der herrschaftlichen und bürgerlichen Küche. 2 Vols. Braun und Schneider.

Sitwell, W. (2013) A History of Food in 100 Recipes. Little, Brown. Strantz, M (1877) Unsere Gemüse: mit Anchluss der Kastanie, Olive, Kaper, der Wein- und Hopfenrebe. Berlin: Enslin.

\section{Secondary Sources}

'Deutsche Biographie - Maximilian II.' Accessed February 15, 2016. http://www.deutsche-biographie.de/sfz70661.html.

'Johann Rottenhöfer,' Project Gutenberg.de, Der Spiegel, <http:// gutenberg.spiegel.de/autor/499>. (accessed 4th March 2014).

'Terra X: Die Geschichte Des Essens: Die Geschichte Des Essens (3/3) - ZDF.de.' Accessed June 26, 2015. http://www.zdf.de/ terra-x/geschichte-des-essens-mit-christian-rach-folge-3nachspeise-37723556.html.

Adamson, M. W, and F. Segan (2008) Entertaining from Ancient Rome to the Super Bowl: An Encyclopedia. ABC-CLIO.

Albala, K. 'The Historical Models of Food and Power in European Courts of the Nineteenth Century: An Expository Essay and Prologue' in Vooght, D. (2013) (ed.) Royal Taste: Food, Power and Status at the European Courts after 1789 pp.13-30. Ashgate Publishing, Ltd.

Ashby, C., T. Gronberg, and S. Shaw-Miller (2013) (eds.) The Viennese Cafe and Fin-de-Siecle Culture. Berghahn Books.

Brown, M. (2006) Eating like a King: A History of Royal Recipes. Stroud: Tempus.

Burnett, J. (2004) England Eats out : A Social History of Eating out in England from 1830 to the Present. 1st edition. Harlow, England; New York: Pearson/Longman.

Burrow, D. I. 'Food at the Russian Court and the Homes of the Imperial Russian Elite,' in Vooght, D. (2013) (ed.) Royal Taste: Food, Power and Status at the European Courts after 1789. pp. 87-110. Ashgate Publishing, Ltd.

Chevallier, B. and M. Walter (2008) Empire Splendor: French Taste in the Age of Napoleon. Vendome Press.

Clarkson, J. (2009) Menus from History: Historic Meals and Recipes for Every Day of the Year. 2 Vols. Santa Barbara, Calif: Greenwood Press.

Crofton, I. (2014) A Curious History of Food and Drink. Quercus.

Elias, N. (2000) The Civilizing Process: Sociogenetic and Psychogenetic Investigations. Revised edition. Oxford ; Malden, Mass: Blackwell Publishing.

Ferguson, P. P. (2004) Accounting for Taste: The Triumph of French Cuisine. Chicago: University of Chicago Press.

Kelly, I. (2009) Cooking for Kings: The Life of Antonin Carême, the First Celebrity Chef. Bloomsbury Publishing USA.

Lair, A. 'The Ceremony of Dining at Napoleon III's Court between 1852 and 1870," in Vooght, D. (2013) (ed.) Royal Taste: Food, 
Power and Status at the European Courts after 1789. pp.

143-170. Ashgate Publishing, Ltd.

Lévi-Strauss, C (1963) Structural Anthropology. New Ed edition. New York: Basic Books.

Lévi-Strauss, C. (1973) The Savage Mind. Nature of Human Society Series. Chicago: University of Chicagp Press.

Lévi-Strauss, C. (1983) The Raw and the Cooked. Lévi-Strauss, Claude. Mythologiques. English; v. 1. Chicago: University of Chicago Press.

Ludington, C. C. 'Drinking for Approval: Wine and the British Court from George III to Victoria and Albert,' in Vooght, D. (2013) (ed.) Royal Taste: Food, Power and Status at the European Courts after 1789. pp. 57-86. Ashgate Publishing, Ltd.

Marchand, Suzanne L. German Orientalism in the Age of Empire: Religion, Race, and Scholarship. Washington, D.C.; Cambridge; New York: German Historical Institute ; Cambridge University Press, 2009.

Mintz, S. W. (1985) Sweetness and Power : The Place of Sugar in Modern History. New York, NY: Viking.

Montanari, M. (2006) Food Is Culture. Columbia University Press.

Neirinck, E. and J.P. Poulain (1988) Histoire de la cuisine et des cuisiniers: techniques culinaires et pratiques de table, en France, du Moyen-Age à nos jours. J. Lanore.

Norbert, N. (1982) Power \& Civility. 1st American edition. New York: Pantheon Books.

Palmer, M. C. S. (1997) La Cocina de Palacio: 1561-1931. Editorial Castalia.
Peterson, T. S. (1994) Acquired Taste: The French Origins of Modern Cooking. 1 edition. Ithaca: Cornell University Press.

Reiser. R. (2000) Das Casino der Roseninsel und ihre Könige. Buchendorfer Verlag $\mathrm{GmbH}$.

Said, E. W. (1979) Orientalism. Random House LLC.

Scholliers, P. 'The Many Rooms in the House: Research on Past Foodways in Modern Europe' in P. Scholliers and K. Claflin, (2012) Writing Food History: A Global Perspective. Pp.59-71. London; New York: Berg.

Sitwell, W. (2013) A History of Food in 100 Recipes. Little, Brown.

Spang, R. L. (2001) The Invention of the Restaurant: Paris and Modern Gastronomic Culture. Cambridge, Mass.: Harvard University Press.

Trubek, A.B. (2000) Haute Cuisine: How the French Invented the Culinary Profession. Philadelphia, Pa.: University of Pennsylvania Press.

Vanessa R Schwartz. Spectacular Realities Early Mass Culture in Fin-de-Siècle Paris. Berkeley: University of California Press, 1998.

Vooght, D. (2013) (ed.) Royal Taste: Food, Power and Status at the European Courts after 1789. Ashgate Publishing, Ltd.

Vooght, D. and P. Scholliers, 'Introduction. Food and Power: Studying Food at (Modern) Courts,' in Vooght, D. (2013) (ed.) Royal Taste: Food, Power and Status at the European Courts after 1789. pp. 1-12. Ashgate Publishing, Ltd. 